\title{
Model Pembelajaran Value Clarification Technique Berbantuan Media Microsoft Powerpoint Untuk Meningkatkan Hasil Belajar PKn
}

\author{
Dewa Ayu Ratih Purnama Sari \\ Program Studi Pendidikan Guru Sekolah Dasar, FIP, Universitas Pendidikan Ganesha, Singaraja, Indonesia \\ aayudewa@gmail.com \\ I Made Tegeh \\ Program Studi Teknologi Pendidikan, FIP, Universitas Pendidikan Ganesha, Singaraja, Indonesia \\ im-tegeh@undiksha.ac.id \\ Ketut Pudjawan \\ Program Studi Teknologi Pendidikan, FIP, Universitas Pendidikan Ganesha, Singaraja, Indonesia \\ ketut.pudjawan@undiksha.ac.id
}

\begin{tabular}{l} 
A R T I C L E I N F O \\
\hline Article history: \\
1 Juli 2020 Received in \\
revised form \\
30 Agustus 2020 \\
Accepted 28 September 2020 \\
Available online \\
30 September 2020 \\
\hline Kata Kunci: \\
VCT, Powerpoint, Hasil \\
Belajar PKn \\
Keywords: \\
VCT, PowerPoint, Learning \\
Outcomes, Civics
\end{tabular}

A R T I C L E I N F O

1 Juli 2020 Received in

revised form

30 Agustus 2020

Available onlin

Kata Kunci:

VCT, Powerpoint, Hasil

Belajar PKn

Outcomes, Civics

\begin{abstract}
AB S T R A K
Pembelajaran yang terpusat pada guru serta kurangnya penggunaan model dan media pembelajaran menyebabkan siswa kurang aktif, dan hasil belajar rendah. Penelitian ini bertujuan untuk mengetahui perbedaan hasil belajar PKn antara kelompok siswa yang dibelajarkan dengan model pembelajaran VCT (Value Clarifications Technique) berbantuan media Microsoft power point dan kelompok siswa yang tidak dibelajarkan dengan model pembelajaran VCT (Value Clarifications Technique) berbantuan media Microsoft power point pada mata pelajaran PKn di kelas IV. Jenis penelitian yang digunakan yaitu eksperimen semu dengan rancangan non equivalent post-test kontrol group design. Populasi dalam penelitian ini adalah siswa kelas IV SD
\end{abstract} yang berjumlah 156 siswa. Teknik pengambilan sampel yang digunakan dalam penelitian ini adalah teknik cluster random sampling. Sampel dalam penelitian ini berjumlah 47 siswa. Berdasarkan hasil data analisis uji t diperoleh nilai signifikansi 2 arah (2-tailed) $0.000<0.05$, sehingga $\mathrm{H}_{0}$ ditolak dan $\mathrm{H}_{1}$ diterima. Ini berarti terdapat perbedaan yang signifikan hasil belajar PKn antara siswa yang mengikuti model pembelajaran VCT (Value Clarification Technique) berbantuan media microsoft power point dan yang tidak menggunakan model pembelajaran VCT (Value Clarification Technique) berbantuan media microsoft power point siswa kelas IV. 
Based on the results of the t-test analysis data, it was obtained a 2-way (2-tailed) significance value of $0.000<0.05$, so that $H O$ was rejected and $H 1$ was accepted. This means that there is a significant difference in Civics learning outcomes between students who follow the VCT (Value Clarification Technique) learning model assisted by Microsoft power point media and those who do not use the VCT (Value Clarification Technique) learning model assisted by power point media for fourth grade students.

\section{PENDAHULUAN}

Pendidikan pada hakikatnya adalah suatu kegiatan yang dilakukan secara sadar dan disengaja untuk menumbuhkan dan mengembangkan pengetahuan dalam rangka membentuk sikap, nilai, dan perilaku. Pendidikan mempunyai peran dan fungsi yang sangat penting dalam kehidupan manusia dan kemajuan suatu negara. Pendidikan yang baik seharusnya sejalan dengan tujuan pendidikan. "Pendidikan merupakan proses mengubah tingkah laku anak didik agar menjadi manusia dewasa yang mampu hidup mandiri” (Sagala, 2009). Tujuan pendidikan mengarah pada kondisi yang diharapkan dalam melaksanakan suatu proses pembelajaran. Vigotsky (dalam Solihatin, 2012) berpendapat bahwa, belajar adalah membangun kerjasama secara sosial dalam mendefinisikan pengetahuan dan lain-lain, yang terjadi melalui pembangunan peluangpeluang secara sosial. Menurut Susanto (2013), hasil belajar merupakan perubahanperubahan yang terjadi pada diri siswa, baik yang menyangkut aspek kognitif, afektif dan psiomotor sebagai hasil dari kegiatan belajar.

Dalam UU No. 20 Tahun 2003 Pasal 37 dicantumkan mata pelajaran wajib diantaranya adalah mata pelajaran PKn. Ardianta dkk (2014) mengatakan bahwa, PKn merupakan bidang kajian kewarganegaraan yangditopang berbagai disiplin ilmu yang relevan, yaitu ilmu politik, hukum, sosiologi, antropologi dan disiplin ilmu lainya yang digunakan sebagai landasan untuk melakukan kajian-kajian terhadap proses pengembangan konsep, nilai dan perilaku demokrasi warga negara. Nurwardani (2016:23) menyatakan bahwa secara etimologis, pendidikan kewarganegaraan berasal dari kata "pendidikan" dan kata "kewarganegaraan". Menurut Susanto (dalam Sariani dkk., 2016: 2), pendidikan kewarganegaraan adalah mata pelajaran yang digunakan sebagai wahana untuk mengembangkan dan melestarikan nilai luhur dan moral yang berakar pada budaya bangsa Indonesia. PKn adalah pendidikan yang mengarahkan siswa agar terbentuk menjadi warga negara yang baik dan bertanggung jawab berdasarkan nilainilai dan dasar Negara Pancasila (Tyas, S. P. \& Mawardi, 2016: 2015). Rismayani (2013) menyatakan bahwa PKn bertujuan mengembangkan potensi individu warganegara, untuk mencapai visi, misi dan tujuan PKn tersebut, seorang guru hendaknya mampu merancang pembelajaran di kelas secara kreatif, dan inovatif. Darmadi (dalam Dianti, 2014:60) menyatakan bahwa, tujuan pembelajaran PKn seperti dijelaskan yaitu membina moral yang diharapkan nantinya dapat diwujudkan dalam kehidupan sehari-hari, yaitu perilaku yang mencerminkan iman dan takwa terhadap Tuhan Yang Maha Esa dalam masyarakat yang terdiri dari berbagai golongan agama, perilaku yang bersifat kemanusiaan yang adil dan beradab, perilaku yang mendukung persatuan bangsa dalam masyarakat yang beraneka ragam, perilaku yang mendukung kerakyatan yang mengutamakan kepentingan bersama di atas kepentingan perorangan dan golongan, pendapatan, ataupun kepentingan di atas melalui musyawarah dan mufakat, serta perilaku yang mendukung upaya untuk mewujudkan keadilan sosial bagi seluruh rakyat indonesia. 
Dilihat dari tujuan pendidikan kewarganegaraan, di sekolah dasar tujuan pendidikan kewarganegaraan belum tercapai secara maksimal. Rejeki (2015) menyatakan bahwa, PKn memiliki tiga komponen yaitu, pengetahuan kewarganegaraan (civic knowledge), keterampilan/kecakapan kewarganegaraan (civic skill), dan sikap/watak kewarganegaraan (civic disposition). Ketiga komponen ini merupakan satu kesatuan yang utuh dimana satu dengan lainnya saling meradiasi (mempengaruhi dengan kuat) sehingga perlu diajarkan secara utuh.Jika salah satu kompenen dihilangkan maka tujuan pembelajaran PKn tidak tercapai secara optimal. Oleh karena itu, dalam pembelajaran PKn dibutuhkan model pembelajaran yang mengacu pada aktivitas yang memungkinkan siswa baik secara individu maupun kelompok aktif mencari, menggali dan menemukan konsep, prinsip, serta nilai-nilai yang terkandung dalam pembelajaran PKn secara keseluruhan.

Setelah dilakukan wawancara, observasi dan studi dokumen pada tanggal 6 Agustus, 18 dan 19 Oktober, dan 26 November 2019 di SD gugus IV Kecamatan Negara,makaditemukan beberapa permasalahan. Tahap pertama yang dilakukan yaitu tahap wawancara, dari hasil wawancara yang telah dilakukan dengan wali kelas IV di SD gugus IV Kecamatan Negara permasalahan yang ditemukan yaitu siswa cenderung pasif di dalam kelas dan cepat merasa bosan, karena kurangnya penggunaan model pembelajaran. Selain itu, siswa juga kurang termotivasi untuk belajar karena kurangnya penggunaan media pembelajaran.

Berdasarkan hasil dari wawancara yang telah dilakukan kemudian peneliti melanjutkan dengan tahap observasi, yaitu mengobservasi proses pembelajaran yang berlangsung di dalam kelas, terutama dalam pelajaran PKn dan diperoleh hasil bahwa siswa masih berpusat pada penjelasan guru dan buku pelajaran yang digunakan. Hal ini dapat dilihat dari masih digunakan metode ceramah yang monoton dalam proses pembelajaran di dalam kelas, sehingga siswa hanya menerima apa yang diberikan oleh gurunya. Selain melakukan wawancara dan observasi, kemudian dilakukan studi dokumen untuk melengkapi hasil wawancara dan observasi, tentang nilai UTS PKn siswa kelas IV semester ganjil di SD gugus IV Kecamatan Negara tahun pelajaran 2019/2020. Rata-rata nilai UTS yang diperoleh siswa kelas IV di SD Gugus IV Kecamatan Negara yaitu 73,88, jika dikonversikan dalam (PAP) menurut Agung (2016) masih berada pada kategori rendah, yang merupakan suatu permasalahan yang harus diatasi. Jika dilihat dari KKM, dari jumlah siswa kelas IV di SD gugus IV Kecamatan Negara yang berjumlah 156 siswa, masih terdapat 90 siswa yang belum mencapai KKM, yang juga merupakan masalah yang harus diatasi. Sehingga dilihat dari nilai KKM dan nilai rata-rata di atas, merupakan suatu masalah yang harus diatasi.

Untuk mengatasi permasalahan tersebut dapat dilaksanakan pembelajaran yang memungkinkan meningkatkan hasil belajar diantaranya dapat menggunakan suatu model pembelajara. Model pembelajaran merupakan kerangka konseptual yang melukiskan prosedur yang sistematis dalam mengorganisasikan pengalaman belajar untuk mencapai tujuan belajar (Santyasa, 2007:7). Model pembelajaran yang digunakan yaitu model pembelajaran Value Clarification Technique (VCT). Menurut Astiti (2017) Model pembelajaran VCT merupakan teknik pengajaran untuk membantu siswa dalam mencari dan menentukan suatu nilai yang dianggap baik dalam menghadapi suatu persoalan melalui proses menganalisis nilai yang sudah ada dan tertanam dalam diri siswa. Model pembelajaran Value Clarification Technique (VCT) adalah "teknik pendidikan nilai 
diamana siswa dilatih untuk menemukan, memilih, menganalisis, membantu siswa dalam mencari dan memutuskan mengambil sikap sendiri mengenai nilai-nilai hidup yang ingin diperjuangkan" Haris (dalam Ekayani, 2019:165). Model pembelajaran VCT merupakan model inovatif yang menekankan pada nilai sosial, budaya, personal, dan masyarakat Putra (dalam Maulida dkk., 2017). Menurut Widayanti dkk (2017), tujuan value clarification technique (VCT) adalah untuk menanamkan nilai-nilai pada siswa melalui analisis nilai yang dilakukan agar siswa terlatih mengambil suatu keputusan dalam penentuan suatu nilai. (Taniredja, 2015:88) menyatakan bahwa Karakteristik Teknik Klarifikasi Nilai (VCT) sebagai suatu model dalam strategi pembelajaran sikap adalah proses penanaman nilai dilakukan melalui proses analisis nilai yang sudah ada sebelumnya dalam diri siswa kemudian menyelaraskannya dengan nilai-nilai baru yang hendak ditanamkan. Dengan demikian model pembelajaran VCT dapat meningkatkan hasil belajar PKN. Adapun langkah-langkah pembelajaran VCT menurut Djahiri (dalam Haris, 2013: 2) antara lain (a) penentuan stimulus, (b) penyajian stimulus melalui peragaan, (c) penentuan posisi/pilihan/pendapat, (d) menguji alasan, (e) penyimpulan dan pengarahan, (f) tindak lanjutan (follow up). Adapun penelitian yang relevan yaitu menurut Widayanti dkk (2017), yang menunjukan hasil penelitian yaitu dengan penerapan model pembelajaran VCT dapat meningkatkan hasil belajar PKn siswa.

Model pembelajaran VCT jika dilakukan dengan berbantuan media Microsoft powerpoint, maka pembelajaran akan lebih baik untuk meningkatkan hasil belajar. Heinich, dkk., (dalam Sutirman, 2013) mengartikan media sebagai perantara yang mengantar informasi dari sumber kepada penerima. Arsyad (dalam Mayasari, 2019:28), secara implisit mengatakan bahwa media pembelajaran meliputi alat yang secara fisik digunakan untuk menyampaikan isi materi pengajaran, yang terdiri dari antara lain buku, tape recorder, kaset, video camera,video recorder film, slide (gambar bingkai) foto, gambar, grafik, televisi, dan komputer. Pemanfaatan media dalam pembelajaran dapat membangkitkan keinginan dan minat baru, meningkatkan motivasi dan rangsangan kegiatan belajar, dan bahkan berpengaruh secara psikologis kepada siswa (hamalik dalam Nurseto, 2011: 22). Wiki (dalam Sukarsa dkk., 2014) menyatakan bahwa, salah satu program komputer sebagai media pembelajaran yang dapat digunakan adalah program microsoft powerpoint. Penggunaan media power point dalam proses pembelajaran dapat merangsang pikiran, perasaan, perhatian, dan kemauan siswa dalam belajar. (Astiti, 2017) menyatakan bahwa, Pada proses pembelajaran dengan menggunakan model pembelajaran VCT berbantuan media power point siswa sangat aktif dan antusias dalam proses pembelajaran, yang muncul ketika siswa diberikan suatu permasalahan, kemudian siswa mementukan suatu nilai yang dianggap baik dan dapat memecahkan masalah tersebut, selain itu siswa juga diberikan beberapa alternatif nilai-nilai yang nantinya akan digunakan untuk menyelesaikan permasalahan yang sedang dipecahkan. Dari pemaparan di atas tentang model pembelajaran VCT dan media Microsoft PowerPoint dapat disimpulkan bahwa model pembelajaran VCT sangat cocok dipadukan dengan media pembelajaran Microsoft Powerpoint. Adapun penelitian yang relevan yaitu yang dilakukan oleh Astiti (2017), yang menunjukan hasil penelitian bahwa dengan penerapan model pembelajaran VCT berbantuan media powerpoint dapat meningkatkan hasil belajar PKn siswa. Adapun perbedaan penelitian ini dengan penelitian yang dilakukan oleh Astiti (2017) yaitu pada subjek penelitiannya. 
Adapun tujuan penelitian ini adalah mengetahui peran model pembelajaran Value Clarification Technique Berbantuan Media Microsoft Powerpoint terhadap peningkatan hasil belajar PKn siswa Kelas IV SD di Gugus IV Kecamatan Negara Tahun Pelajaran 2019/2020 dengan meneliti siginifikasi pengaruh dari model pembelajaran Value Clarification Technique Berbantuan Media Microsoft Powerpoint terhadap hasil belajar PKn siswa.

\section{METODE PENELITIAN}

Penelitian ini menggunakan penelitian eksperimen. Penelitian eksperimen dilakukan untuk mengetahui pengaruh model pembelajaran terhadap permasalahan yang terjadi di sekolah dasar. Berdasarkan hasil wawancara, observasi, dan studi kasus yang telah dilakukan di SD Gugus IV Kecamatan Negara Tahun Pelajaran 2019/2020 ditemukan beberapa permasalah yaitu: (1) Siswa cenderung pasif di dalam kelas dan cepat merasa bosan, karena kurangnya penggunaan model pembelajaran. (2) Siswa kurang termotivasi untuk belajar karena kurangnya penggunaan media pembelajaran. (3) Siswa masih berpusat pada penjelasan guru dan buku pelajaran yang digunakan. (4) Rendahnya hasil belajar PKn siswa kelas IV semester ganjil.

Penelitian ini dilakukan dengan beberapa langkah atau tahapan yang terdapat dalam prosedur penelitian ini yaitu tahap persiapan, tahap pelaksanaan, dan tahap akhir penelitian. Adapun uraian dalam setiap tahapan yaitu: pada tahap persiapan hal yang dilakukan adalah 1) Meminta izin kepada kepala sekolah untuk melaksanakan penelitian di SD Gugus IV Kecamatan Negara. 2) Melakukan wawancara dengan wali kelas IV, terkait masalah yang dihadapi dalam proses pembelajaran di kelas. 3) Melakukan observasi di kelas IV guna mencari data awal di Gugus IV Kecamatan Negara tersebut. 4) Melakukan uji kesetaraan pada populasi untuk menentukan sampel penelitian. Berdasarkan hasil uji kesetaraan menyatakan bahwa sebagian besar sekolah setara. 5) Menentukan dua kelas sebagai sampel penelitian dengan teknik random sampling melalui sistem pengundian, yaitu di kelas IVA sebagai kelas kontorl dan IVB sebagai kelas eksperimen di SD Gugus IV Kecamatan Negara. 6) Merancang perangkat pembelajaran berupa RPP, merancang tes yang akan digunakan sebagai post-test, merancang lembar penilaian, dan mengkonsultasikan instrument penelitian yang telah disusun ke dosen pembingbing. 7) Melakukan uji coba instrumen penelitian, kemudian dianalisis yang meliputi uji validitas, uji reliabilitas, uji taraf kesukaran, dan uji daya beda tes. 8) Merevisi instrumen penelitian yang telah diujikan agar menghasilkan butir-butir soal yang benar-benar layak.

Kemudian pada tahap pelaksanaan hal yang dilakukan adalah 1) Peneliti berkoordinasi dengan guru kelas di sekolah tempat melakukan penelitian dan menentukan sampel penelitian. 2) Peneliti menjelaskan kepada guru mengenai model pembelajaran, perangkat pembelajaran, dan instrument yang akandigunakan. 3) Guru melaksanakan pembelajaran dengan menerapkan model pembelajaran VCT berbantuan Microsoft PowerPointpada kelas eksperimen sedangkan pada kelas kontrol tidak diterapkan model pembelajaran VCT berbantuan Microsoft PowerPoint. 4) Peneliti melakukan observasi terhadap proses pembelajaran pada kelas eksperimen dan kelas kontrol untuk mengetahui proses pembelajaran yang dilaksanakan. 5) Peneliti melakukan analisis dan evaluasi terhadap efektivitas pembelajaran dengan model pembelajaran VCT berbantuan 
Microsoft PowerPoint dan ketercapaian tujuan, yaitu meningkatan Hasil Belajar PKn siswa di kelas IV.

Pada tahap akhir penelitian hal yang dilakukan adalah 1) Peneliti mengadakan post-test (tes akhir) pada kelas eksperimen dan kelas control. 2) Melakukan analisis data berdasarkan data hasil belajar PKn siswa kelompok eksperimen dan kelompok kontrol, untuk menguji hipotesis yang diajukan. 3) Menarik kesimpulan.

Jenis penelitian ini adalah penelitian eksperimen semu (quasi experiment). Adapun rancangan penelitian yang digunakan adalah post-test only control group design. Populasi dalam penelitian ini adalah seluruh kelas IV di SD Gugus IV Kecamatan Negara tahun pelajaran 2019/2020, berjumlah 156 siswa yang terbagi dalam 5 SD, yaitu: SDN 1 Tegal Badeng Barat, SDN 2 Tegal Badeng Barat, SDN 3 Tegal Badeng Barat, SDN 1 Cupel, SDN 2 Cupel. Distribusi populasi penelitian dapat dilihat pada tabel 02.

Tabel 02 Daftar Populasi Penelitian

\begin{tabular}{|c|c|c|c|}
\hline No & Sekolah & Kelas & Jumlah \\
\hline 1. & $\begin{array}{l}\text { SD Negeri } 1 \text { Tegal Badeng } \\
\text { Barat }\end{array}$ & IV & 34 \\
\hline 2. & $\begin{array}{l}\text { SD Negeri } 2 \text { Tegal Badeng } \\
\text { Barat }\end{array}$ & IV & 43 \\
\hline 3. & $\begin{array}{l}\text { SD Negeri } 3 \text { Tegal Badeng } \\
\text { Barat }\end{array}$ & IV & 14 \\
\hline 4. & SD Negeri 1 Cupel & IVA & 22 \\
\hline 5. & SD Negeri 1 Cupel & IVB & 25 \\
\hline 6. & SD Negeri 2 Cupel & IV & 18 \\
\hline \multicolumn{3}{|c|}{ Jumlah } & 156 \\
\hline
\end{tabular}

Dalam populasi penelitian dilakukan uji kesetaraan di kelas IV SD Gugus IV Kecamatan Negara dengan menggunakan analisis Anava satu jalur. Kriteria Anava satu jalur yaitu apabila hasil yang diperoleh dengan taraf signifikansi $5 \%$ jika $\mathrm{F}_{\text {hitung }}<\mathrm{F}_{\text {tabel }}$ maka $\mathrm{H}_{0}$ diterima dan $\mathrm{H}_{\mathrm{a}}$ ditolak, artinya tidak ada pengaruh secara signifikan dan apabila $\mathrm{F}_{\text {hitung }}>\mathrm{F}_{\text {tabelmaka }} \mathrm{H}_{0}$ ditolak dan $\mathrm{H}_{\mathrm{a}}$ diterima, artinya ada pengaruh secara signifikan. Pengambilan sampel menggunakan teknik cluster random sampling, sehingga mendapatkan kelas eksperimen yaitu kelas IVB SDN 1 Cupel dengan jumlah siswa 25 orang dan kelas kontrol yaitu kelas IVA SDN 1 Cupel dengan jumlah siswa 22 orang. Kelompok eksperimen dibelajarkan dengan model pembelajaran VCT berbantuan media Microsoft Power Point, sedangkan kelompok kontrol tidak dibelajarkan dengan model pembelajaran VCT berbantuan media Microsoft Power Point.

Penelitian ini memiliki 2 variabel yaitu diantaranya variabel terikat dan variabel bebas. Menurut Agung, (2014:42) "variabel bebas yaitu satu atau lebih dari variabelvariabel yang sengaja dipelajari pengaruhnya terhadap variabel tergantung". Variabel bebas yang digunakan dalam penelitian ini yang akan diberikan perlakuan pada kelompok eksperimen adalah model pembelajaran Value Clarification Technique berbantuan media Microsoft PowerPoint. Menurut (Agung, 2014) "variabel terikat adalah variabel yang keberadaanya atau munculnya bergantung pada variabel bebas". Variabel terikat yang digunakan dalam penelitian ini adalah Hasil Belajar PKn pada siswa kelas IVB SD Gugus IV Kecamatan Negara. 
Pengumpulan data dalam penelitian ini adalah menggunakan tes hasil belajar PKn siswa kelas IV SD. Tes yang digunakan dalam penelitian ini yaitu tes objektif yang digunakan pada akhir pembelajaran untuk mengukur kemampuan siswa. Instrumen yang digunakan untuk pengumpulan data hasil belajar PKn menggunakan tes objektif yang berbentuk pilihan ganda dengan jumlah 30 butir soal kemudian diuji menggunakan analisis yang telah ditentukan. Soal ini dibuat berdasarkan dengan kisi-kisi yang telah disusun sebelumnya.

Setelah instrumen penelitian selesai, kemudian dilakukan uji coba untuk mengetahui kelayakan instrument penelitian yang digunakan dalam penelitian. Instrumen penelitian dapat dikatakan baik apabila sudah memenuhi dua persyaratan penting, yaitu uji validitas dan uji realibilitas. Data yang diperlukan dalam penelitian ini adalah data tentang pencapaian kompetensi pengetahuan siswa pada mata pelajaran PKn di sekolah dasar. Instrumen yang digunakan untuk mengukur tingkat prestasi siswa yaitu berupa tes objektif tentang kemampuan hasil belajar. Setelah instrumen penelitian selesai, kemudian dilakukan uji coba untuk mengetahui kelayakan instrument penelitian yang digunakan dalam penelitian. Data yang telah diperoleh dari uji coba instrumen selanjutnya dianalisis dengan menggunakan uji valididtas, uji reliabilitas, daya beda dan tingkat kesukaran tes.

Dalam penelitian ini menggunakan teknik analisis data, dimana teknik analisis data ini dilakukan untuk memahami data yang telah didapat, dan menarik kesimpulan yang terkait dengan karakteristik data yang didapat dari sampel penelitian. Sebelum melaksanakan analisis data varians terlebih dahulu dilakukan analisis data deskriptif. Analisis deskriptif yang dilakukan pada penelitian ini untuk mendeskripsikan hasil belajar PKn pada kelompok eksperimen yang diberikan perlakuan dengan model pembelajaran Value Clarification Technique berbantuan media microsft powerpoint dan kelompok kontrol dengan perlakuan model konvensional. Adapaun analisis deskriptif yang digunakan yaitu: mean, median, dan modus.

Sebelum uji hipotesis dilakukan terdapat beberapa tahapan yang harus dilalui yaitu uji normalitas dan uji homogenitas. Haniah (2014:3) menyatakan bahwa, tujuan uji normalitas adalah untuk mengetahui apakah data yang diperoleh dari hasil sebuah penelitian berdistribusi normal atau tidak. Yulida (2018:3) menyatakan bahwa, uji homogenitas dilakukan untuk memastikan bahwa kelompok yang dibandingkan merupakan kelompok yang mempunyai varians homogen.

Setelah data yang didapat telah diuji prasyarat, selanjutnya dilakukan uji hipotesis. Uji hipotesis dapat dijabarkan menjadi hipotesis nol $\left(\mathrm{H}_{0}\right)$ dan hipotesis alternatif $\left(\mathrm{H}_{1}\right)$. Metode analisis yang digunakan dalam menguji hipotesis penelitian ini adalah statistik uji-t (polled varians).

\section{HASIL DAN PEMBAHASAN}

\section{HASIL}

Sebelum uji hipotesis dilakukan ada beberapa tahapan yang harus dilakukan yaitu pengujian prasyarat, yang terdiri dari uji normalitas dan uji homogenitas terhadap data hasil belajar PKn. Uji normalitas sebaran data yang diuji menggunakan teknik Kolmogorov-Smirnov dan Shapiro-Wilk menggunakan bantuan SPSS 16.0 for windows. Berdasarkan output tabel SPSS, diketahui bahwa nilai Sig. sebesar 0.092 dimana $>0.05$. Maka sesuai dengan dasar pengambilan keputusan dalam uji normalitas Kolmogorov- 
smirnov, dapat disimpulkan bahwa data berdistribusi normal. Dengan demikian persyaratan atau asumsi normalitas terpenuhi.

Pada uji homogenitas varians dilakukan dengan menggunakan Test of Homogeneity of Variance dengan bantuan SPSS 16.0 for windows. Dikatakan mempunyai nilai varians yang sama apabila taraf signifikansinya yaitu $\geq 0.05$ dan jika taraf signifikansinya $<0.05$ maka data disimpulkan tidak mempunyai nilai varians yang sama (tidak homogen). Data hasil dari uji homogenitas dengan metode Levene's Test. Diperoleh nilai Sig. 0.129 dimana > 0.05 yang berarti terdapat kesamaan varians (homogen) antar kelompok. Dengan demikian, persyaratan atau asumsi data homogen terpenuhi.

Berdasarkan uji prasyarat analisis data yang sudah dilakukan, maka diperoleh data bahwa data hasil belajar adalah normal dan homogen. Setelah diperoleh data hasil uji prasyarat analisis data, maka analisis dilanjutkan pengujian hipotesis penelitian $\left(\mathrm{H}_{1}\right)$ dan Hipotesis nol $\left(\mathrm{H}_{0}\right)$. Uji Hipotesis menggunakan uji t dengan bantuan SPSS 16.0 for windows. Dasar penentuan uji T Test Independent berdasarkan nilai signifikansi (2-tailed) yang mengukur ada tidaknya perbedaan rata-rata pada subjek yang diujikan. Berdasarkan hasil uji Independent Sample T-test nilai post-test diperoleh hasil seperti tabel 04 berikut.

Tabel 04 Hasil uji Independent Sample T-test

\begin{tabular}{|c|c|c|c|c|c|c|c|c|c|c|}
\hline & & \multicolumn{2}{|c|}{$\begin{array}{l}\text { Levene's } \\
\text { Test for } \\
\text { Equality of } \\
\text { Variances }\end{array}$} & \multicolumn{7}{|c|}{ t-test for Equality of Means } \\
\hline & & \multirow[b]{2}{*}{$\mathbf{F}$} & \multirow[b]{2}{*}{ Sig. } & \multirow[b]{2}{*}{$\mathbf{T}$} & \multirow[b]{2}{*}{ Df } & \multirow{2}{*}{$\begin{array}{l}\text { Sig. (2- } \\
\text { tailed) }\end{array}$} & \multirow{2}{*}{$\begin{array}{c}\text { Mean } \\
\text { Differen } \\
\text { ce }\end{array}$} & \multirow{2}{*}{$\begin{array}{l}\text { Std. } \\
\text { Error } \\
\text { Diffe } \\
\text { rence }\end{array}$} & \multicolumn{2}{|c|}{$\begin{array}{l}95 \% \text { Confidence } \\
\text { Interval of the } \\
\text { Difference }\end{array}$} \\
\hline & & & & & & & & & Lower & Upper \\
\hline \multirow[t]{2}{*}{ Hasil } & $\begin{array}{l}\text { Equal } \\
\text { variances } \\
\text { assumed }\end{array}$ & 2.390 & .129 & -7.552 & 45 & .000 & -10.702 & 1.417 & -13.556 & -7.848 \\
\hline & $\begin{array}{l}\text { Equal } \\
\text { variances not } \\
\text { assumed }\end{array}$ & & & -7.469 & 41.346 & .000 & -10.702 & 1.433 & -13.595 & -7.809 \\
\hline
\end{tabular}

Berdasarkan tabel 04, nilai sig pada kolom sig (2-tailed) dan baris equal variances assumed sebesar 0.000. Dapat dilihat nilai signifikansi 2 arah (2-tailed) $0.000<0.05$. Sehingga $\mathrm{H}_{0}$ ditolak dan $\mathrm{H}_{1}$ diterima.

Pada penelitian ini, hasil analisis data menunjukan bahwa terdapat perbedaan hasil belajar PKn antara kelompok siswa yang dibelajarkan dengan model pembelajaran VCT berbantuan media Microsoft Powerpoint dan yang tidak dibelajarkan dengan model pembelajaran VCT berbantuan media Microsoft Powerpoint pada siswa kelas IV di SD Gugus IV Kecamatan Negara Tahun Pelajaran 2019/2020. Hal ini ditinjau berdasarkan hasil analisis uji-t dan rata-rata skor hasil belajar siswa. Berdasarkan analisis data menggunakan uji-t dengan bantuan SPSS 16.0 for windows, diketahui nilai sig pada kolom sig (2-tailed) dan baris equal variances assumed sebesar 0.000. Dapat dilihat nilai signifikansi 2 arah (2-tailed) $0.000<0.05$. Sehingga $\mathrm{H}_{0}$ ditolak dan $\mathrm{H}_{1}$ diterima. Hasil ini menyatakan bahwa terdapat perbedaan hasil belajar PKn siswa antara kelompok siswa yang dibelajarkan menggunakan model VCT berbantuan media Microsoft Powerpoint 
dengan siswa yang tidak dibelajarkan menggunakan model VCT berbantuan media Microsoft Powerpoint pada siswa kelas IV di SD Gugus IV Kecamatan Negara Tahun Pelajaran 2019/2020.

\section{PEMBAHASAN}

Berdasarkan hasil yang diperoleh, perbedaan yang signifikan pada hasil belajar PKn antara kelompok siswa yang dibelajarkan dengan model pembelajaran VCT berbantuan media Microsoft Powerpoint dengan siswa yang tidak dibelajarkan menggunakan model VCT berbantuan media Microsoft Powerpoint pada dasarnya dapat disebabkan oleh beberapa faktor. Pertama, pada model pembelajaran VCT dalam langkah-langkahnya terdapat banyak implikasi yang mengacu pada mata pelajaran PKn, sehingga model pembelajaran VCT sangat cocok digunakan pada mata pelajaran PKn. Haris (dalam Ekayani, 2019) menyatakan bahwa model pembelajaran Value Clarification Technique (VCT) adalah teknik pendidikan nilai diamana siswa dilatih untuk menemukan, memilih, menganalisis, membantu siswa dalam mencari dan memutuskan mengambil sikap sendiri mengenai nilai-nilai hidup yang ingin diperjuangkan. Hal serupa juga dipaparkan oleh Sariani dkk (2016), yaitu hasil penelitian menunjukkan perbedaan yang signifikan antara siswa yang dibelajarkan menggunakan model pembelajaran VCT dengan siswa yang dibelajarkan tidak menggunakan model pembelajaran VCT.

Pembelajaran dengan menggunakan model VCT menekankan aktivitas belajar siswa melalui tahap penyajianmedia yang berupa media Microsoft Powerpoint, menentukan, menghargai, bertindak, adanya penekanan nilai refleksi dan kesimpulan. Pada tahap awal pembelajaran guru menyajikan media Microsoft Powerpoint kepada siswa untuk merangsang motivasi siswa dalam belajar yang berupa gambar. Setelah penyajian media selesai, guru memberikan suatu permasalahan kepada siswa berupa cerita yang harus di analisis dan meminta siswa secara berkelompok menentukan cara penyelesaian masalah tersebut. Siswa harus mampu meyakini dan menghargai nilai akan pilihannya. Setelah pilihan siswa sudah tertanam pada diri, siswa menyajikan hasil pilihannya di depan kelas serta diharapkan siswa dapat bertindak sesuai dengan pilihannya tersebut. Kemudian guru memberikan penekanan pada nilai yang dipilih siswa yang mana sekiranya dapat dilakukan. Selanjutnya melakukan refleksi dan merumuskan kesimpulan atas pembelajaran yang telah dilakukan. Pembelajaran dengan model VCT dapat meningkatkan hasil belajar siswa dalam mata pelajaran PKn terutama pada penekanan nilai-nilai.

Kerjasama antar siswa dalam berdiskusi antar kelompoknya, dalam menyelesaikan suatu permasalahan dapat mengacu pada keaktifan dan kreatifitas siswa sehingga membantu proses pembelajaran jadi lebih efektif dan dapat meningkatkan hasil belajar siswa. Dalam diskusi kelompok siswa juga mendapatkan pelajaran mengenai cara bersosialisasi antar kelompoknya, saling menghargai dan menghormati pendapat orang lain,guna mendapatkan kesepakatan bersama. Dengan demikian, dalam berdiskusi kelompok dapat membantu siswa agar mudah memahami materi pembelajaran yang diajarkan, serta meningkatkan pemahaman konsep. Sejalan dengan pendapat Ur (dalam Tamah, 2017), Kerja kelompok adalah suatu bentuk pengaktifan siswa yang memberi kesempatan siswa berlatih berbicara, memperbesar tanggung jawab dan kemandirian siswa, menaikkan motivasi, dan menyumbangkan perasaan kooperatif dan kehangatan dalam kelas. Sesuai dengan langkah-langkah pada model pembelajaran VCT maka 
penggunaan model pembelajaran VCT berbantuan media Microsoft Powerpoint pada mata pelajaran PKn sangat cocok digunakan untuk meningkatkan hasil belajar PKn.

Wiki (Sukarsa et al., 2014) menyatakan bahwa, salah satu program komputer sebagai media pembelajaran yang dapat digunakan adalah program Microsoft powerpoint. Microsoft powerpoint merupakan aplikasi presentasi dalam komputer yang penggunaannya mudah, karena program powerpoint ini dapat diintegrasikan dengan microsoft lainnya seperti word, excel, access dan sebagainya (Susilana, dalam Andriani 2016:43). Yanti (2013) menyatakan bahwa, media pembelajaran berupa media power point digunakan untuk mendesain proses pembelajaran kesuasana yang lebih menarik sehingga siswa termotivasi untuk mengikuti proses pembelajaran. Powerpoint juga merupakan salah satu program di bawah microsoft office program komputer dan tampilan ke layar dengan menggunakan bantuan LCD proyektor Sanaky, ( dalam Andriani, 2016). Suprapti (2016:59) menyatakan bahwa, Microsoft PowerPoint merupakan program untuk membuat presentasi dengan fasilitas yang ada dapat digunakan untuk membuat media pembelajaran, program yang dihasilkan cukup menarik jika di gabungkan dengan menggunakan software Ispring Presenter yang dapat merubahnya menjadi media animasi dalam bentuk flash.

(Astiti, 2017) menyatakan bahwa, Pada proses pembelajaran dengan menggunakan model pembelajaran $V C T$ berbantuan media power point siswa sangat aktif dan antusias dalam proses pembelajaran, yang muncul ketika siswa diberikan suatu permasalahan, kemudian siswa mementukan suatu nilai yang dianggap baik dan dapat memecahkan masalah tersebut, selain itu siswa juga diberikan beberapa alternatif nilai-nilai yang nantinya akan digunakan untuk menyelesaikan permasalahan yang sedang dipecahkan. Dari pemaparan di atas tentang model pembelajaran VCT dan media Microsoft PowerPointdapat disimpulkan bahwa model pembelajaran VCT sangat cocok dipadukan dengan media pembelajaran Microsoft PowerPoint. Karena model pembelajaran VCT menekankan pada nilai-nilai yang dapat dipaparkan semenarik mungkin di Microsoft PowerPointyang merupakan media presentasiyang dapat merangsang rasa ingin tahu siswa, guna meningkatkan hasil belajar siswa.

Berbeda halnya dengan tidak menggunakan model pembelajaran VCT berbantuan media Microsoft PowerPoint atau menggunakan model pembelajaran konvensional yang lebih didominasi pada guru. Langkah pembelajaran model konvensional dimulai dari pemberian informasi dari guru berupa ceramah, tanya jawab, pemberian tugas dan pelaksanaan tugas oleh siswa. Pembelajaran konvensional menjadikan siswa hanya berperan sebagai pendengar,sehingga siswa pasif di dalam kelas, yang dapat menimbulkan kejenuhan pada diri siswa untuk belajar. Komunikasi yang terjalin dalam pembelajaran ini hanya komunikasi satu arah yaitu komunikasi antara guru dengan siswa. Sedangkan, siswa tidak diberi kesempatan untuk mengeksplor suatu masalah dengan pikirnya sendiri. Ini yang menyebabkan siswa menjadi pasif dan materi yang diajarkan akan susah diterima oleh siswa.

Berdasarskan rata-rata skor yang telah diperoleh menunjukkan bahwa, kedua kelompok mempunyai masing-masing 22 sampel kelas kontrol dan 25 sampel kelas eksperimen. Tes akhir kelompok kelas eksperimen lebih tinggi dari kelompok kelas kontrol dilihat dari rata-ratanya yaitu pada kelas eksperimen 86.52 sedangan, pada kelas kontrol 75.82. Hal ini menunjukan bahwa hasil belajar PKn kelompok siswa pada kelas eksperimen yang dibelajarkan dengan model pembelajaran VCT berbantuan media 
Microsoft Powerpoint lebih tinggi dibandingkan dengan kelompok siswa pada kelas control yang tidak dibelajarkan dengan model pembelajaran VCT berbantuan media Microsoft Powerpoint di kelas IV Gugus IV Kecamatan Negara tahun Pelajaran 2019/2020.

Terdapat beberapa hasil penelitian yang relevan dengan penelitian ini, yang dapat digunakan sebagai pedoman dalam penelitian ini. Adapun penelitian yang relevan yaitu yang dilakukan oleh (Astiti, 2017), yang menunjukan hasil penelitian terdapat perbedaan hasil belajar yang signifikan antara kelompok siswa yang dibelajarkan dengan model pembelajaran VCT berbantuan media powerpoint dan kelompok siswa yang dibelajarkan dengan tidak menggunakan model pebelajaran VCT pada siswa kelas V SD Gugus II Kecamatan Buleleng tahun pelajaran 2016/2017. Sejalan dengan penelitian tersebut, menurut (Widayanti, I. A. V., Suwatra, I. I. W., \& Made Sumantri, 2017), yang menunjukan hasil penelitian yaitu terdapat perbedaan kelopok eksperimen dan kelompok control menunjukan bahwa penerapan model pembelajaran value clarification technique (VCT) berpengaruh positif terhadap hasil belajar PKn, dibandingkan dengan pembelajaran yang menerapkan model pembelajaran konvensional. Dengan demikian model pembelajaran VCT dapat meningkatkan hasil belajar PKn siswa kelasa V di SD gugus IV kecamatan Sukasada. (Putriani, 2017) menyatakan bahwa, terdapat perbedaan yang signifikan hasil belajar PKn antara kelompok siswa yang dibelajarkan dengan model pembelajaran Value Clarification Technique (VCT) berbasis masalah sosial dan kelompok siswa yang dibelajarkan dengan model pembelajaran konvensional pada siswa kelas $\mathrm{V}$ SD di Gugus V Kecamatan Karangasem Tahun Pelajaran 2016/2017.

Dengan demikian hasil penelitian ini membuktikan bahwa model pembelajaran VCT berbantuan media Microsoft Powerpoint dapat memberi pengaruh terhadap hasil belajar siswa, yaitu dalam meningkatkan hasil belajar PKn. Hal ini dapat dilihat dari pembelajaran model pembelajaran VCT berbantuan media Microsoft Powerpoint lebih banyak menekankan keterlibatan dan keaktifan siswa dengan melakukan kegiatan diskusi kelompok sedangkan, guru hanya bertugas sebagai fasilitator dan motivator dalam pelaksanaan pembelajaran.

\section{SIMPULAN}

Berdasarkan hasil pengujian hipotesis serta analisis yang telah dilakukan maka terdapat pengaruh positif model pembelajaran VCT berbantuan media Microsoft Powerpoint terhadap hasil belajar PKn siswa kelas IV di SD Gugus IV Kecamatan Negara Tahun Pelajaran 2019/2020. Ini berarti bahwa model pembelajaran Value Clarification Technique Berbantuan Media Microsoft Powerpoint berperan dalam meningkatkan hasil belajar PKn siswa kelas IV di SD Gugus IV Kecamatan Negara Tahun Pelajaran 2019/2020.

\section{DAFTAR PUSTAKA}

Agung, A. A. . (2014). Metodologi Penelitian Pendidikan. Aditya Media Publishing.

Agung, A. A. G. (2016). Statistika Dasar Untuk Pendidikan. Deepublish.

Andriani, M. R. (2016). Pengembangan Media Pembelajaran Power Point Interaktif Melalui Pendekatan Saintifik untuk Pembelajaran Tematik Integratif Siswa Kelas 2 SDN Bergas Kidul 03 Kabupaten Semarang. Scholaria: Jurnal Pendidikan Dan 
Kebudayaan, 6(1), 143-157.

Ardianta, I. W., Imran, I., \& Septiwiharti, D. (2014). Meningkatkan Hasil Belajar Siswa Pada Pembelajaran PKn Dengan Menggunakan Metode Tanya Jawab di Kelas V SDN 3 Kasimbar. Jurnal Kreatif Online, 2(3).

Astiti, N. K. A. (2017). Pengaruh Model Pembelajaran VCT berbantuan Media Power Point Terhadap Hasil Belajar PKn Pada Siswa Kelas V Semester II Tahun Pelajaran 2016/2017 Di SD Gugus II Kecamatan Buleleng.

Dianti, P. (2014). Integrasi Pendidikan Karakter dalam pembelajaran Pendidikan Kewarganegaraan untuk mengembangkan karakter siswa. Jurnal Pendidikan Ilmu Sosial, 23(1).

Ekayani, N. W. (2019). Pengaruh Model Pembelajaran Value Clarification Technique (VCT) Terhadap Karakter. Mimbar PGSD Undiksha, 7(1).

Haniah, N. (2014). Uji Normalitas dengan Metode Liliefors.

Haris, F. (2013). Penerapan Model Pembelajaran VCT (Value Clarification Technique) untuk meningkatkan kesadaran nilai menghargai jasa pahlawan pada siswa sekolah dasar. Jurnal Penelitian Pendidikan Guru Sekolah Dasar, 1(2), 1-11.

Maulida, A., Sudarma, I. K., \& Japa, I. G. N. (2017). Pengaruh Model Pembelajaran Value Clarification Technique (VCT) Bermediakan Video Terhadap Hasil Belajar PKn Siswa Kelas V. MIMBAR PGSD Undiksha, 5(2).

Mayasari, N. (2019). Peranan Model Pembelajaran Value Clarification Technique Berbantuan Media Audio Visual Untuk Meningkatkan Hasil Belajar IPS. Jurnal Pendidikan, 20(1), 53-58.

Nurseto, T. (2011). Membuat media pembelajaran yang menarik. Jurnal Ekonomi Dan Pendidikan, 8(1).

Nurwardani. (2016). Pendidikan Kewarganegaraan. Direktorat Jendral Pembelajaran dan Kemahasiswaan Kementerian Riset Teknologi dan Pendidikan Tinggi.

Putriani. (2017). Pengaruh Model Pembelajaran Value Clarification Technique (VCT) Bermediakan Video Terhadap Hasil Belajar PKn Siswa Kelas V. MIMBAR PGSD Undiksha, 5(2). https://doi.org/10.23887/jjpgsd.v5i2.11003

Rejeki, S. (2015). Penggunaan Model Pembelajaran Value Clarification Technique (VCT) Untuk Meningkatkan Civic Dispositionpada Mata Pelajaran Pkn Siswa Kelas V SDN Kalasan 1 Sleman. BASIC EDUCATION, 4(6).

Rismayani, N. L. (2013). Penerapan Model Pembelajaran Discovery Learning Untuk Meningkatkan Hasil Belajar Pkn Siswa. Jurnal Pendidikan Kewarganegaraan Undiksha, 1(2).

Sagala, S. (2009). Konsep dan Makna Pembelajaran. Alfabeta.

Santyasa, I. W. (2007). Model-model pembelajaran inovatif.

Sariani, N. K. D., Dantes, N., \& Parmiti, D. P. (2016). Pengaruh Model Pembelajaran Value Clarification Technique (Vct) Terhadap Sikap Sosial Dan Hasil Belajar Mata Pelajaran Pkn Pada Siswa Kelas IV SD. Mimbar Pgsd Undiksha, 4(1).

Solihatin, E. (2012). Strategi Pembelajaran PPKN. Bumi Aksara. 
Sukarsa, I. W., Dantes, N., \& Arini, N. W. (2014). Penerapan model pembelajaran kuantum berbantuan media Microsoft Powerpoint untuk meningkatkan aktivitas dan hasil belajar ipa siswa kelas IV semester 1 SD Negeri 6 Menanga. MIMBAR PGSD Undiksha, 2(1).

Suprapti, E. (2016). Pengembangan perangkat pembelajaran matematika model kooperatif tipe STAD dengan media powerpoint Ispring pada materi jajargenjang, layang-layang dan trapesium di kelas VII SMP. MUST: Journal of Mathematics Education, Science and Technology, 1(1), 57-68.

Susanto, A. (2013). Teori Belajar dan Pembelajaran di Sekolah Dasar. Kencana Prenada Media Group.

Sutirman. (2013). Media \& Model-Model Pembelajaran Inovatif. Graha Ilmu.

Tamah, S. M. (2017). Pernak-Pernik Kerja Kelompok Berbasis Pembelajaran Kooperatif.

Taniredja, T. (2015). Model-Model Pembelajaran Inovatif dan Efektif.

Tyas, S. P., \&l, \& Mawardi, M. (2016). Keefektifan Model Pembelajaran Value Clarification Technique dalam Mengembangkan Sikap Siswa. Satya Widya, 32(2), 103-116.

UU No. 20 Tahun 2003 pasal 37.

Widayanti, I. A. V., Suwatra, I. I. W., \& Made Sumantri, M. P. (2017). engaruh Model Pembelajaran Value Clarification Technique (Vct) Terhadap Hasil Belajar Pkn Siswa Kelas V Di Sd Gugus Iv Kecamatan Sukasada. Mimbar PGSD Undiksha, $5(2)$.

Widayanti, I. A. V., Suwatra, I. I. W., \& Made Sumantri, M. P. (2017). Pengaruh Model Pembelajaran Value Clarification Technique (Vct) Terhadap Hasil Belajar Pkn Siswa Kelas V Di Sd Gugus Iv Kecamatan Sukasada. Mimbar PGSD Undiksha, $5(2)$.

Yanti, N. W. W. (2013). Penerapan Model Pembelajaran PBL Berbantuan Power Point Untuk Meningkatkan Hasil Belajar PKn. Jurnal Pendidikan Kewarganegaraan Undiksha, 1(2).

Yulida, F. (2018). Implementasi Model Pembelajaran Kooperatif Metode Two Stay Two Stray (Tsts) Terhadap Hasil Belajar Materi Pengertian Dokumen Dan Dokumentasi Siswa Kelas X Apk Di Smkn 10 Surabaya. Jurnal Administrasi Perkantoran (JPAP), 5(3). 